\title{
REVIEW
}

\section{Detection of coins ingested by children using a handheld metal detector: a systematic review}

\author{
J B Lee, S Ahmad, C P Gale
}

Emerg Med J 2005;22:839-844. doi: 10.1136/emj.2004.022301

To determine if the use of a handheld metal detector (HHMD) can safely reduce the number of radiographs requested in cases of coins ingested by children, a search was performed to identify prospective studies of the ability of an HHMD to identify the presence or absence of ingested coin in children (17 years or younger). Outcome measures were presence or absence of coin on metal detector screening, and accuracy of coin localisation. Inclusion and exclusion criteria were defined. MantelHaenszel (fixed effect model) pooling with 95\% confidence intervals $(\mathrm{Cl})$ was used to calculate overall sensitivities and specificities. In total, 11 studies met the inclusion criteria. The overall sensitivity of the HHMD at detecting the presence of coins was $99.4 \%(95 \% \mathrm{Cl} 98.0$ to $99.9 \%)$ and accuracy at localisation was $99.8 \%$ (98.5 to $100.0 \%)$. The overall specificity of the HHMD was $100 \%$ (76.8 to $100 \%)$. Use of the HHMD is an accurate, radiation free, and cost effective method of identifying and localising coins ingested by children. An algorithm for investigating children with coin ingestion is proposed.

See end of article for authors' affiliations

Correspondence to: Mr J Lee, Accident and Emergency Department St James's University Hospital, Leeds LS9 7TF, UK; docjasonlee@hotmail. com

Accepted for publication 21 December 2004
$\mathrm{F}$ oreign body ingestion by children is common. In the UK, ${ }^{1}$ and other countries worldwide, $^{2-7}$ the ingested object that most frequently results in hospital attendance is a metal coin. A postal survey of parents in the US found that $4 \%$ of children had swallowed a coin at some time. ${ }^{8}$ Recognised complications of unidentified coins in the oesophagus include perforation and mediastinitis, ${ }^{10}$ tracheooesophageal fistula, ${ }^{11}$ and sudden death. ${ }^{12}{ }^{13}$ Although the proportion of patients who are symptomatic following coin ingestion ranges from $7 \%$ to $64 \%$, depending on the study chosen, ${ }^{14}{ }^{15}$ there is consensus that absence of symptoms does not exclude the presence of an impacted coin. Hence, most patients undergo radiological investigation. The use of a metal detector to determine presence or absence of metal foreign bodies as an alternative to standard radiographs has been advocated for more than 30 years, ${ }^{16}$ yet, despite obvious advantages (time and lack of radiation) over standard radiographs, metal detector use has not been widely adopted in the UK.

The aim of this review was to determine if the use of a handheld metal detector (HHMD) could safely reduce the number of radiographs requested in cases of coins ingested by children.

\section{METHODS}

\section{Criteria for selection of studies}

Only prospective assessments of the ability of an HHMD to identify the presence or absence of ingested coins in children ( 17 years or below) were included. Outcome measures had to include either presence or absence of coin on metal detector screening, or accuracy of coin localisation. Case reports, editorials, and opinions were excluded.

Studies were scored for internal and external validity and were excluded if the following criteria were not met. (a) The gold standard (radiograph(s)) was applied in all cases regardless of result. The gold standard investigation was considered to be a chest radiograph as a minimum. Serial radiographs, performed until a coin was located or excluded, were considered an acceptable alternative. (b) The HHMD operator was blinded to the results of the gold standard investigation.

\section{Search strategy}

The Embase (1980-Oct. week 2 2004), Medline (1966-Oct. week 2 2004), OldMedline (19511965), Medline In-Process \& Non-Indexed Citations (Oct. 14 $\left.{ }^{\text {th }} 2004\right)$, CINAHL (1982-Oct. week 2 2004), Allied and Complimentary Medicine (1985-Sep. 2004) and EBM Reviews (Oct. 2004) databases were searched via the OVID interface using the following terms: [ (exp numismatics OR coin\$.mp. OR exp foreign bodies OR foreign bod\$.mp.) AND (pediatric\$.mp. OR paediatric\$.mp. OR child\$.mp. OR exp pediatrics) AND (detect\$.tw. OR metal.tw.) ]. We did not restrict by country or language of publication.

The following journals were hand searched by two authors (JL, SA) for issues covering January 1980-September 2004: Emergency Medical Journal (Journal of Accident and Emergency), Annals of Emergency Medicine, Pediatrics, European Journal of Pediatrics, Academic Emergency Medicine, and Journal of Otolaryngology.

Two authors (JL, CG) independently reviewed the abstracts retrieved from the search and selected which studies were to be included. If there was insufficient information from the abstract to decide, the full version of the paper was requested. Bibliographies of retrieved papers were scanned for further relevant studies.

Abbreviation: HHMD, handheld metal detector 
Table 1 Characteristics of included studies

\begin{tabular}{|c|c|c|c|c|c|}
\hline $\begin{array}{l}\text { Author, date } \\
\text { and country }\end{array}$ & Patient group & Study type & Reference standard & Outcome measures & Comments \\
\hline $\begin{array}{l}\text { Muensterer OJ et al, } \\
\text { 2004, Germany }\end{array}$ & $\begin{array}{l}65 \text { consecutive children } \\
\text { presenting to an ED over } \\
20 \text { months with suspected or } \\
\text { witnessed MFB ingestion }\end{array}$ & Diagnostic & $\begin{array}{l}\text { Serial radiographs } \\
\text { (abdomen }+/- \text { chest } \\
+/- \text { neck) }\end{array}$ & $\begin{array}{l}\text { Presence or absence of MFB } \\
\text { on scan. MFB localisation to } \\
\text { chest or abdomen }\end{array}$ & $\begin{array}{l}\text { Uzman Tracker IV } \mathrm{IV}^{10} \text { model. } \\
\text { Coins present in } 25 \text { patients. } 2 \\
\text { false positives }\end{array}$ \\
\hline $\begin{array}{l}\text { Schalamon J et al, } \\
\text { 2004, Austria }\end{array}$ & $\begin{array}{l}53 \text { consecutive children } \\
\text { presenting to an ED with } \\
\text { suspected MFB ingestion }\end{array}$ & Diagnostic & Chest radiograph & $\begin{array}{l}\text { Presence or absence of MFB } \\
\text { on scan. MFB localisation to } \\
\text { chest or abdomen. }\end{array}$ & $\begin{array}{l}\text { MV9 Proxxon model }{ }^{\boxplus} \text {. Coins } \\
\text { present in } 34 \text { patients }\end{array}$ \\
\hline $\begin{array}{l}\text { Younger R et al, } \\
2001 \text {, US }\end{array}$ & $\begin{array}{l}26 \text { children referred from EDs } \\
\text { with radiologically proven } \\
\text { oesophageal coins (at least } 6 \\
\text { hours earlier) }\end{array}$ & Diagnostic & $\begin{array}{l}\text { Repeat radiographs } \\
\text { of chest and } \\
\text { abdomen }\end{array}$ & $\begin{array}{l}\text { MFB localisation to chest or } \\
\text { abdomen }\end{array}$ & $\begin{array}{l}\text { Garrett Super-Scanner model. } \\
1 \text { patient refused } 2 \text { nd } \\
\text { radiograph and was excluded } \\
\text { from the study. Coins present in } \\
25 \text { patients. }\end{array}$ \\
\hline $\begin{array}{l}\text { Gooden E et al, } \\
2000 \text {, Canada }\end{array}$ & $\begin{array}{l}10 \text { children presenting to an ED } \\
\text { with suspected foreign body } \\
\text { ingestion, or transferred from } \\
\text { another centre }\end{array}$ & Diagnostic & $\begin{array}{l}\text { Repeat radiographs } \\
\text { of chest, neck, and } \\
\text { abdomen }\end{array}$ & $\begin{array}{l}\text { MFB localisation to chest or } \\
\text { abdomen }\end{array}$ & $\begin{array}{l}\text { Heiman MHG model. } \\
\text { Investigators were not blinded to } \\
\text { radiographs of transferred } \\
\text { patients. Coins present in } 9 \\
\text { patients }\end{array}$ \\
\hline $\begin{array}{l}\text { Bassett KE et al, } \\
\text { 1999, US }\end{array}$ & $\begin{array}{l}62 \text { consecutive children } \\
\text { presenting to an ED with } \\
\text { suspected coin ingestion, and } \\
29 \text { children referred with } \\
\text { radiographically proven } \\
\text { oesophageal coin (at time of } \\
\text { referral) }\end{array}$ & Diagnostic & $\begin{array}{l}\text { Serial radiographs } \\
\text { (chest }+/- \text { abdomen } \\
+/- \text { neck) }\end{array}$ & $\begin{array}{l}\text { Presence or absence of coin } \\
\text { on scan. Coin localisation to } \\
\text { chest or abdomen. }\end{array}$ & $\begin{array}{l}\text { Garrett Super-Scanner model. } \\
\text { Operators received }<1 \text { min of } \\
\text { training. Coins present in } 54 \text { of } \\
\text { the patients presenting directly } \\
\text { to the ED. } 1 \text { coin not identified in } \\
\text { the oesophagus. } 1 \text { oesophageal } \\
\text { coin incorrectly localised to the } \\
\text { stomach area }\end{array}$ \\
\hline $\begin{array}{l}\text { Doraiswamy NV et al, } \\
\text { 1999, UK }\end{array}$ & $\begin{array}{l}231 \text { children presenting to an } \\
\text { ED with suspected MFB ingestion }\end{array}$ & Diagnostic & Chest radiograph & $\begin{array}{l}\text { Presence or absence of MFB } \\
\text { on scan. MFB localisation to } \\
\text { chest or abdomen. }\end{array}$ & $\begin{array}{l}\text { Adams AD } 18 \text { model. Coins } \\
\text { present in } 146 \text { patients. } 8 \text { false } \\
\text { positives. }\end{array}$ \\
\hline $\begin{array}{l}\text { Seikel K et al, } \\
\text { 1999, US }\end{array}$ & $\begin{array}{l}176 \text { consecutive children } \\
\text { presenting to } 2 \text { children's } \\
\text { hospitals with suspected MFB } \\
\text { ingestion examined by } \\
\text { "inexperienced" scanners, } 140 \\
\text { of whom were also seen by } \\
\text { "experienced" scanners }\end{array}$ & Diagnostic & Chest radiograph & $\begin{array}{l}\text { Presence or absence of MFB } \\
\text { on scan. MFB localisation to } \\
\text { chest or abdomen }\end{array}$ & $\begin{array}{l}\text { Garrett Super-Scanner model. } \\
\text { Coins present in } 60 \text { patients. } 6 \\
\text { false positives. MFBs were only } \\
\text { missed in the inexperienced } \\
\text { group }\end{array}$ \\
\hline $\begin{array}{l}\text { Tidey B et al, } \\
\text { 1996, UK }\end{array}$ & $\begin{array}{l}20 \text { children presenting to an ED } \\
\text { with suspected foreign body } \\
\text { ingestion }\end{array}$ & Diagnostic & $\begin{array}{l}\text { Serial radiographs } \\
\text { (chest }+/- \text { abdomen } \\
+/- \text { neck) }\end{array}$ & $\begin{array}{l}\text { Presence or absence of MFB } \\
\text { on scan. MFB localisation to } \\
\text { chest or abdomen }\end{array}$ & $\begin{array}{l}\text { Adams AD } 15^{\infty} \text { model. Coins } \\
\text { present in } 8 \text { patients. }\end{array}$ \\
\hline $\begin{array}{l}\text { Sachetti A et al, } \\
1994 \text {, US }\end{array}$ & $\begin{array}{l}23 \text { children presenting to an ED } \\
\text { with suspected MFB ingestion }\end{array}$ & Diagnostic & Chest radiograph & $\begin{array}{l}\text { Presence or absence of MFB } \\
\text { on scan. MFB localisation to } \\
\text { chest or abdomen }\end{array}$ & $\begin{array}{l}\text { Garrett Super-Scanner and } \\
\text { Enforcer } G 2^{\infty} \text { model. Coins } \\
\text { present in } 6 \text { patients. }\end{array}$ \\
\hline $\begin{array}{l}\text { Biehler JL et al, } \\
\text { 1993, US }\end{array}$ & $\begin{array}{l}19 \text { consecutive children } \\
\text { presenting to an ED with } \\
\text { suspected coin ingestion and } 11 \\
\text { children referred with proven } \\
\text { oesophageal coin }\end{array}$ & Diagnostic & $\begin{array}{l}\text { Serial radiographs } \\
\text { (chest }+/- \text { abdomen } \\
+/- \text { neck }+/- \\
\text { lateral chest) }\end{array}$ & $\begin{array}{l}\text { Presence or absence of coin } \\
\text { on scan. Coin localisation to } \\
\text { chest or abdomen. }\end{array}$ & $\begin{array}{l}\text { Backpacker-2 TR }{ }^{1} \text { model. Coins } \\
\text { present in } 27 \text { patients. Areas } \\
\text { used to document localisation } \\
\text { were: above clavicles, } \\
\text { substernal, or abdominal }\end{array}$ \\
\hline $\begin{array}{l}\text { Ros S et al, } \\
1992, \text { US }\end{array}$ & $\begin{array}{l}14 \text { consecutive children } \\
\text { presenting to an ED with } \\
\text { suspected coin ingestion }\end{array}$ & Diagnostic & $\begin{array}{l}\text { Chest and } \\
\text { abdominal } \\
\text { radiographs. }\end{array}$ & $\begin{array}{l}\text { Presence or absence of coin } \\
\text { on scan. Coin localisation to } \\
\text { chest or abdomen }\end{array}$ & $\begin{array}{l}\text { Garrett Super-Scanner model. } \\
\text { Coins present in } 11 \text { patients. } 1 \\
\text { coin in the rectum not identified. } \\
\text { Only the anterior neck, chest, } \\
\text { and abdomen were scanned }\end{array}$ \\
\hline
\end{tabular}

Finally, experts in paediatric medicine, paediatric surgery, radiology, emergency medicine, and otolaryngology were contacted to identify further papers or unpublished data. In the event of disagreement the decision of a third author (SA) was final.

\section{Search results and study quality}

The search strategy employed retrieved 1039 citations, of which 12 articles met the criteria for the review. Agreement was total between authors for the 12 studies chosen for inclusion. The quality of included studies was good but this could only be concluded after contact with the authors for six studies, because of inadequate reporting of methodology. All studies were prospective, blinded, and used an appropriate reference test. The study characteristics have been tabulated (table 1).

\section{Data extraction and analysis}

Data was independently extracted from the papers by two authors (JL, SA) and doubly entered into Meta-DiSc software (version 1.1.1). Where studies included all types of ingested metal foreign body, only the subset data for coins was used to calculate sensitivity at coin identification, and accuracy of localisation. Only data from studies purely investigating ingested coins was used to calculate specificities. Where studies included patients referred from secondary centres with radiologically proven oesophageal coins, those patients were excluded from the analysis of ability to identify coin presence, but were still included in analysis of accuracy of coin localisation (provided this was confirmed on a second radiograph) as coins could have moved en route. Only data from doctor or radiographer operators, with prior instruction on how to use the HHMD, however brief, was used in the pooled analysis. If studies localising coins used a variety of descriptions of location areas, the areas were dichotomised into abdominal (below the xiphisternum) or non-abdominal (xiphisternum or above).

The authors of one study, Arena et al, ${ }^{17}$ reported a $100 \%$ sensitivity and specificity using the HHMD on 28 children but could not be contacted. Owing to the inadequate reporting of type of metal objects ingested, data for coins alone could not be extracted, and this paper was excluded. Nine studies 
remained for analysis of the ability of the HHMD ability to identify coins, and 11 studies remained for the analysis of its ability to localise coins (table 2). Mantel-Haenszel (fixed effect model) pooling with $95 \%$ confidence intervals was used to calculate sensitivities and specificities (fig 1). Handling of zeros was performed by adding 0.5 to zero cell studies. The $\chi^{2}$ test was performed to assess study heterogeneity. Predictive values, likelihood ratios, and diagnostic odds ratios are not useful in this clinical setting and were therefore not calculated.

\section{RESULTS}

The included studies showed no evidence of heterogeneity for sensitivity $\left(\chi^{2}=8.0, p=0.43\right)$ or specificity $\left(\chi^{2}=0, p=1.0\right)$. The overall sensitivity of the HHMD at detecting the presence of coins was $99.4 \%$ (95\% confidence interval (CI) 98.0 to $99.9 \%$ ) and accuracy at localisation was $99.8 \%$ (98.5 to $100.0 \%)$. The overall specificity of the HHMD was $100 \%(76.8$ to $100 \%)$.

\section{DISCUSSION}

Most metal detectors work on the basis that metal objects cause a disturbance in an electromagnetic field, passing between a transmitter and receiver, triggering an audiovisual signal. When attempting to identify an ingested metal foreign body with an HHMD, false positive results may be caused by metal implants and wires remaining in situ following thoracic surgery, nearby wall fixtures, trolleys, patient or parental jewellery, metal clasps, zips, buttons, or belt buckles. Ideally, for the scan, a child should wear a gown, and should stand or be held away from walls. The majority of studies identifying ingested metal foreign bodies have effectively employed techniques of vertically scanning the chest from chin to xiphoid, horizontally across the abdomen, and horizontally down the back.

Of the 11 studies included in our final analysis, ${ }^{18-28}$ some are worthy of further scrutiny because they serve to highlight potential limitations of the ability of the HHMD to detect metal foreign bodies. Schalamon et a ${ }^{19}$ correctly identified all 32 coins ingested by children in their study, using an HHMD. However, 8 of 15 non-coin metal foreign bodies were not identified, including two button batteries and a needle. Similar difficulties have been reported by other investigators, ${ }^{18} 26$ and the message appears clear that HHMDs may not be reliable at excluding the presence of metal foreign bodies other than coins. The study of Basset et al2 correctly identified 53 of 54 coins but missed one oesophageal coin

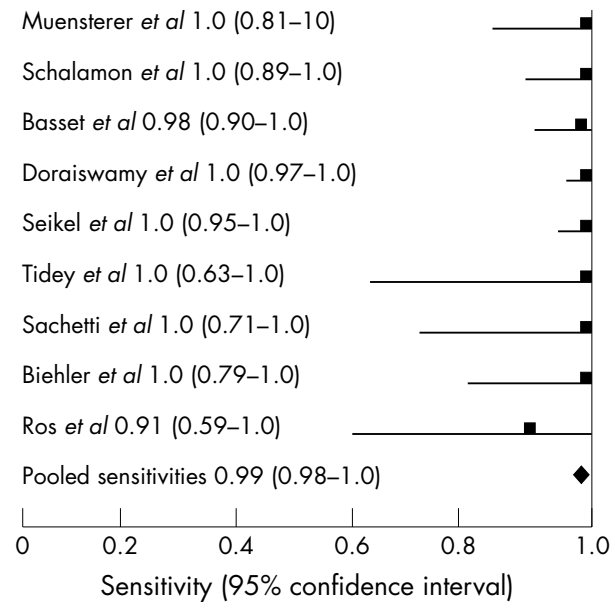

Figure 1 Sensitivity graph of HHMD at identifiying coins ingested by children from included studies. in a 9 year old child weighing $64 \mathrm{~kg}$. The coin could not be identified with the HHMD, even after radiographic localisation and re-scanning. As most studies were performed in the US, with its recognised child obesity problems, simply being overweight would appear not be a contraindication to use of the HHMD. Profound obesity, however, with the resultant increase in scanner to object distance, should be considered a relative contraindication to exclusion of an oesophageal coin by HHMD. The only other reported missed coin, in a study by Ros and Cetta, ${ }^{28}$ was located in the rectum. Their technique of only scanning the neck, chest, and abdomen anteriorly may explain this. Studies that have included the sacral area in the scan have successfully identified rectal coins. ${ }^{17} 23$

Three studies reported false positive results. Doraiswamy et $a^{23}$ had eight false positive scan results when using the HHMD to detect suspected ingested metal foreign bodies in 231 children. After excluding children with metal implants (two sternotomy wires), and removing likely external sources of false positives (mother's ring, a trouser zip, a coin in the pocket, a metal button, a belt buckle, and in two cases, a steel chair), re-scanning proved negative in all cases. Seikel et $a^{24}$ and Muensterer et $a l^{18}$ reported eight false positives between them but gave no further details. Seikel et al, however, did report a case of ingested aluminium not seen on the radiograph but clearly identified by HHMD scanning. The low radiodensity of aluminium makes it almost "invisible" on radiographs, and the superiority of an HHMD at identifying ingested aluminium objects has been documented elsewhere. ${ }^{29-31}$

Seikel et $a^{21}$ attempted to show that no training was required to be able to use the HHMD effectively. A convenience sample of non-doctors (such as porters and receptionists), with no previous experience in the use of a HHMD followed written instructions and scanned a maximum of one child each. This "inexperienced" group missed one coin and incorrectly localised 2 of 124 coins. The "experienced" group (doctors with up to 1 hour's practice), missed no coins and localised all objects correctly. Only Basset et $a^{22}$ reported a coin incorrectly localised by an operator with prior training in the use of an HHMD. However, this study was designed to show that a minimum of training is necessary to allow the HHMD to be used effectively, with each operator given a demonstration of its use lasting $<1$ minute. Incorrect localisation has not been reported in any study with "experienced" operators. The use of the HHMD is simple, but familiarity with its use appears beneficial. At present, no validated training programme exists on how to use the HHMD to identify ingested coins. Logically, any training should include a discussion of potential causes of false positive and false negative results, and a demonstration of the basic features of the HHMD. Subsequently, a "see one, do one (supervised), teach one" approach appears well suited to the development of proficiency with the technique.

Applying meta-analysis techniques to diagnostic studies is a relatively recent concept, and guideline developers ${ }^{32} 33$ have expressed concern over study heterogeneity and poor reporting of study methodology. In such cases, the statistics are complex and the validity is questionable. However, when diagnostic studies have similar methodologies and there is homogeneity of results, as is the case here, the proportions of the studies can be simply added together to derive sensitivity and specificities. ${ }^{34}$ The pooled estimate of sensitivity of the ability of the HHMD to detect ingested coins was 99.4\% (95\% CI $98.0 \%$ to $99.9 \%$ ) and its accuracy at localisation was $99.8 \%$ (98.5 to $100.0 \%$ ) The pooled specificity at identifying swallowed coins was $100 \%$ (76.8 to $100 \%$ ), but patient numbers were low because of exclusion of trials investigating all metal foreign bodies. 
Table 2 Extracted data from included studies examining the ability of the handheld metal detector to identify and localise ingested coins in children

\begin{tabular}{|c|c|c|c|c|c|c|}
\hline Authors & $\begin{array}{l}\text { Coins } \\
\text { correctly } \\
\text { identified }\end{array}$ & $\begin{array}{l}\text { Coins } \\
\text { "missed" }\end{array}$ & $\begin{array}{l}\text { Coins } \\
\text { correctly } \\
\text { localised } \\
\text { to chest or } \\
\text { abdomen }\end{array}$ & $\begin{array}{l}\text { Coins } \\
\text { incorrectly } \\
\text { localised to } \\
\text { chest or } \\
\text { abdomen }\end{array}$ & $\begin{array}{l}\text { MFBs } \\
\text { correctly } \\
\text { excluded }\end{array}$ & $\begin{array}{l}\text { False } \\
\text { positives } \\
\text { for an } \\
\text { ingested } \\
\text { MFB }\end{array}$ \\
\hline Muensterer OJ et al & 25 & 0 & 25 & 0 & 22 & 2 \\
\hline Schalamon J et al & 32 & 0 & 32 & 0 & 6 & 0 \\
\hline Bassett KE et al & 53 & 1 & 81 & 1 & $8^{*}$ & 0 \\
\hline Doraiswamy NV et al & 146 & 0 & 138 & 0 & 48 & 8 \\
\hline Seikel K et al & 50 & 0 & $50 \dagger$ & $0 \dagger$ & $\ddagger$ & 6 \\
\hline Tidey B et al & 8 & 0 & 8 & 0 & 5 & 0 \\
\hline Sachetti $A$ et al & 11 & 0 & 11 & 0 & 6 & 0 \\
\hline Biehler JL et al & 16 & 0 & 27 & 0 & $3^{*}$ & 0 \\
\hline Ros $\mathrm{S}$ et al & 10 & 1 & 10 & 0 & $3^{*}$ & 0 \\
\hline Gooden E et al & - & - & 9 & 0 & - & - \\
\hline Younger $\mathrm{R}$ et al & - & - & 26 & 0 & - & - \\
\hline Total & 351 & 2 & 417 & 1 & $101\left(14^{*}\right)$ & 16 \\
\hline
\end{tabular}

Statistics can complicate even the most straightforward of matters. Quite simply, of 351 children with radiographically identified coins, only two were not identified by the HHMD, with plausible explanations offered for both. Only one of 417 coins identified was incorrectly localised, by an operator with $<$ l minute of instruction. Of contacted authors who continue to use the HHMD, none could provide new data because they no longer perform confirmatory radiographs on patients with negative scans or those with positive scans below the epigastrium. Combined, these authors ${ }^{1822} 2326$ represent a period of over 20 years of HHMD investigation of coin ingestion by children in the emergency department. None could recall a complication from a missed coin. Although anecdotal, complications from ingested coins missed by the HHMD must be rare, and have not yet been reported.

Children with coins located at the level of the xiphisternum should have confirmatory radiographs to exclude impaction at the gastro-oesophageal junction, whereas children with coins localised below the xiphisternum can forego radiographic investigation. Accurate localisation of coins to the abdomen is important because such cases can be managed conservatively. We could find only one report of a coin below the diaphragm that required surgical intervention. ${ }^{35}$ The patient was a 22 year old woman who had ingested an American "penny" 3 weeks earlier. The coin had caused a local reaction in the area of the ileocaecal valve and the resulting $10 \mathrm{~cm}$ inflammatory mass had precipitated small bowel obstruction. The reaction was thought to be a consequence of the corrosive effect of gastric acid on this particular coin, the composition of which is $97.5 \%$ zinc.

Currently, advice given to parents of children with ingested coins is not standardised. Particularly with infants, they may be advised to examine each stool for the coin. The study of Schalamon et a ${ }^{19}$ is interesting in this respect. Despite parents of children with proven abdominal coins claiming that every stool was examined for a coin and none found, six of 12 children who returned a week later no longer had radiological evidence of coin presence. The practice of examining stools is messy and unreliable, and may raise anxiety levels when the coin is not seen to pass. As intervention would only be considered in symptomatic patients, advising parents to return if the coin has not passed in a week or two appears futile. There is no cutoff period after which management would change. Therefore, parents should be advised to return only if the child becomes symptomatic (abdominal pain, vomiting, or rectal bleeding).

This review has potential limitations. It is possible that all relevant studies have not been found. The number and range of journals in which similar studies could be published in is vast. Logistically, only the journals considered most likely to yield relevant papers were hand searched. Diagnostic studies are considered more prone to publication bias than randomised controlled trials ${ }^{36}$ and, despite contacting experts, it is possible that negative studies remain unidentified. Of the studies that were included, most documented that consecutive patients were enrolled but few documented the number of eligible children not enrolled, raising the possibility of selection bias. Finally, the ability to detect a coin may be dependent upon the device chosen or the composition of the coin. However, sensitivities of $100 \%$ were found with a variety of HHMD models, and no difficulties were found with identification of US, UK, or European coins.

In line with most electrical items, the cost of HHMDs has reduced over the years. Schalamon et al ${ }^{19}$ demonstrated a sensitivity of coin identification of $100 \%$ with an HHMD purchased for $€ 15$ in a tool shop (2004) while the Garrett Super-Scanner ${ }^{\circledR}$, used in most studies, ${ }^{20} 22242628$ is available on the internet for $\$ 149(£ 87)$ at the time of writing. Running costs are dependent only on battery costs. Departmental variation and recent conversion to PACS makes costing of radiographs difficult. Figures of $£ 22, £ 26$, and $£ 30$ for lateral neck, chest, and abdominal radiographs, respectively, have been quoted in the literature. ${ }^{23}{ }^{37}$ Thus, it would take only four cases (based on the cost of a single radiograph) of ingested coins excluded by a HHMD to cover the initial cost of the device, with all subsequent negative scans or scans localising coins to the abdomen representing direct savings. Few UK studies have documented the incidence of children presenting to the emergency department with suspected coin ingestion. Doraiswamy et a ${ }^{23}$ noted 124 in 18 months in Glasgow. By comparison, Tidey et al ${ }^{25}$ noted only 13 in 1 year in Brighton, but acknowledged that the majority would have been seen at the local children's hospital.

The benefit of reduced patient time spent in the department for those foregoing radiological investigation will be obvious not only to the child and parents, but to all facing the current 4 hour target. ${ }^{38}$ Others may identify a reduction in the number of children exposed to potentially harmful ionising radiation as the main advantage of the HHMD. A telephone and internet survey of UK emergency consultants conducted by us in October 2004 revealed that of the 50 departments sampled, only five possessed a metal detector (unpublished data). The commonest reasons given for not using a HHMD were cost and doubt over its accuracy. This 


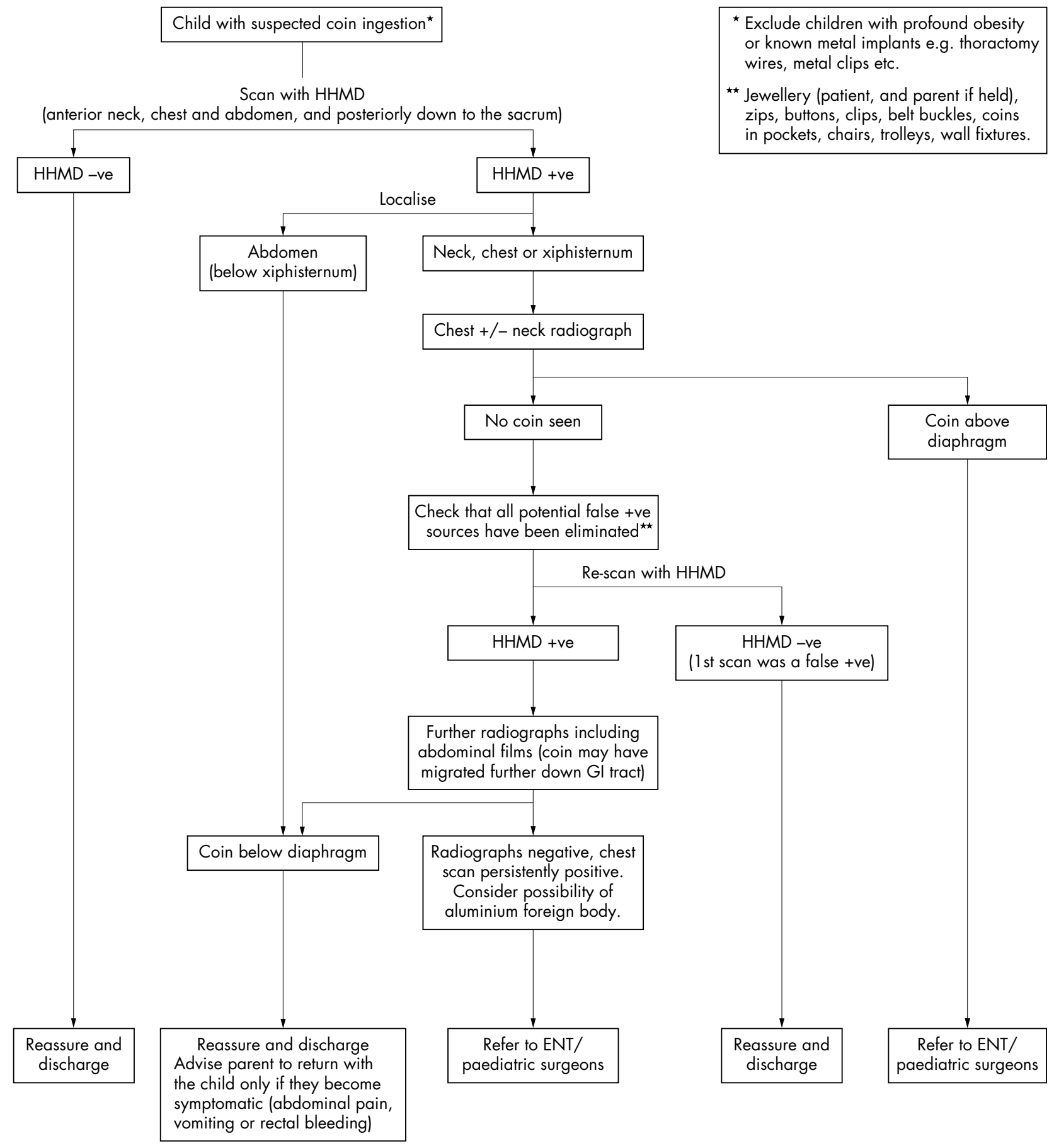

Figure 2 Algorithm for the investigation of children with suspected coin ingestion.

view may have been based upon the historically higher costs of the HHMD and wide confidence intervals around sensitivity values published in small studies. Evidence has now been presented to challenge both points.

In fig 2, we present a proposed algorithm for the investigation of a child with a suspected ingested coin.

\section{CONCLUSION}

The HHMD is accurate, radiation free, and cost effective at identifying and localising coins ingested by children. The use of a HHMD by all UK emergency departments is overdue. Personnel who operate the device should have a demonstration and practice session before use, and be alerted to possible causes of false negative and false positive results.

\section{ACKNOWLEDGEMENTS}

We would like to thank O J Muensterer, N V Doraiswamy, A Sacchetti, and K Bassett for replying to requests for data clarification, and to all responding experts for information regarding ongoing studies.

\section{Auth....................}

Authors' affiliations

J B Lee, S Ahmad, Leeds General Infirmary, Leeds, UK C P Gale, Pinderfields General Hospital, UK

Competing interests: none declared 


\section{REFERENCES}

1 Stringer MD, Kiely EM, Drake DP. Gastric retention of swallowed coins after pyloromyotomy. Br J Clin Pract 1991;45:66-7.

2 Lin MT, Yeung CY, Lee HC, et al. Management of foreign body ingestion in children: experience with 42 cases. Acta Paediatr Taiwan 2003;44:269-73.

3 Benito Navarro J, Porras Alonso E. Esophageal foreign bodies: our ten years of experience. Acta Otorrinologologica Espanola 2003;54:281-5.

4 Uba AF, Sowande AO, Amusa YB, et al. Management of oesophageal foreign bodies in children. East Afr Med J 2002;79:334-8.

5 Mahafza T, Batieha A, Suboh M, et al. Esophageal foreign bodies: a Jordanian experience. Int J Pediatr Otorhinolaryngol 2002;64:225-7.

6 Nijhawan S, Shimpi L, Mathur A, et al. Management of ingested foreign bodies in upper gastrointestinal tract: report on 170 patients. Indian J Gastroenterol 2003;22:46-8.

7 van $A s A B$, du Toit N, Wallis $L$, et al. The South African experience with ingestion injury in children. Int J Pediatr Otorhinolaryngol 2003;67/suppl 1):S175-8

8 Conners GP, Chamberlain JM, Weiner PR. Pediatric coin ingestion: A home based survey. Am J Emerg Med 1995; 13:538-40.

9 Tucker JG, Kim HH, Lucas GW. Esophageal perforation caused by coin ingestion. South Med J 1994:87:269-72.

10 Kerschner JE, Beste DJ, Conley SF, et al. Mediastinitis associated with foreign body erosion of the oesophagus in children. Int J Pediatr Otolaryngol 2001;59:89-97.

11 Obiako MN. Tracheoesophageal fistula. A complication of foreign body. Ann Otol Rhinol Laryngol 1982;91:325-7.

12 Dahiya M, Denton JS. Esophageal perforation by foreign body (coin) causing sudden death in a 3-yr-old child. Am J Forensic Med Pathol 2001;120:184-8.

13 Byard RW, Moore L, Bourne AJ. Sudden and unexpected death-a late effect of occult intraesophageal foreign body. Pediatr Pathol 1990;10:837-41.

14 Conners GP, Chamberlain JM, Ochsenschlager DW. Symptoms and spontaneous passage of esophageal coins. Arch Pediatr Adolesc Med 1995; 149:36-9

15 Suita S, Ohgami H, Nagasaki A, et al. Management of pediatric patients who have swallowed foreign objects. Am Surg 1989;55:585-90.

16 Wolter JR, Wolter $\mathrm{KH}$. A simple and inexpensive metal detector for magnetic and nonmagnetic metallic foreign bodies. Trans Am Ophthalmol Soc 1974:72:363-7

17 Arena L, Baker SR. Use of a metal detector to identify ingested metallic foreign bodies. AJR Am J Roentgenol 1990;155:803-4.

18 Muensterer OJ, Joppich I. Identification and topographic localization of metallic foreign bodies by metal detector. J Paediatr Surg 2004;39:1245-8.

19 Schalamon JHE, Ainoedhofer $\mathrm{H}$, et al. The use of a hand-held metal detecto for localisation of ingested metallic foreign bodies - a critical investigation. Eur J Pediatr 2004; 163:257-9.
20 Younger RM Darrow DH. Handheld metal detector confirmation of radiopaque foreign bodies in the esophagus. Arch Otolaryngol Head Neck Surg 2001; 127:1371-4

21 Gooden EA, Forte V, Papsin B. Use of a commercially available metal detector for the localization of metallic foreign body ingestion in children. J Otolaryngol 2000;29:218-20.

22 Bassett KE, Schunk JE, Logan L. Localizing ingested coins with a metal detector. Am J Emerg Med 1999;17:338-41.

23 Doraiswamy N, Baig H, Hallam L. Metal detector and swallowed metal foreign bodies in children. Emerg Med J 1999;16:123-5.

24 Seikel K, Primm PA, Elizondo BJ, et al. Handheld metal detector localization of ingested metallic foreign bodies: accurate in any hands? Arch Pediatr Adolesc Med 1999;153:853-7.

25 Tidey B, Price G, Perez-Avilla C, et al. The use of a metal detector to locate ingested metallic foreign bodies in children. Emerg Med $J$ $1996 ; 13: 341-2$.

26 Sacchetti A, Carraccio C, Lichenstein R. Hand-held metal detector identification of ingested foreign bodies. Pediatr Emerg Care 1994:10:204-7.

27 Biehler JL, Tuggle D, Stacy T. Use of the transmitter-receiver metal detector in the evaluation of pediatric coin ingestions. Pediatr Emerg Care 1993;9:208-10.

28 Ros SP, Cetta F. Successful use of a metal detector in locating coins ingested by children. J Pediatr 1992;120:752-3.

29 Bradburn DM, Carr HF, Renwick I. Radiographs and aluminium: a piffall for the unwary. BMJ 1994;308:1226.

30 Stewart GD, Lakshmi MV, Jackson A. Aluminium ring pulls: an invisible foreign body. J Accid Emerg Med 1994;11:201-3.

31 Ryan J, Perez-Avila CA, Cherukuri A, et al. Using a metal detector to locate a swallowed ring pull. J Accid Emerg Med 1995;12:64-5.

32 Deville WL, Buntinx F, Bouter LM, et al. Conducting systematic reviews of diagnostic studies: didactic guidelines. BMC Med Res Methodol 2002;2:9.

33 Cochrane Methodology Group on Screening and Diagnostic Tests. Recommended methods. www.cochrane.org/cochrane/sadt.htm.

34 Deeks JJ. Systematic reviews in health care: Systematic reviews of evaluations of diagnostic and screening tests. BMJ 2001;323:157-62.

35 Tupesis JP, Kaminski A, Patel H, et al. A penny for your thoughts: small bowel obstruction secondary to coin ingestion. J Emerg Med 2004; 27:249-52

36 Irwig L, Macaskill P, Glasziou, et al. Meta-analytic methods for diagnostic test accuracy. J Clin Epidemiol 1995;120:667-76.

37 The Royal College of Radiologists, London. Making the best use of a department of clinical radiology. In: Guidelines for doctors, 4th ed, 1998.

38 Department of Health. The NHS Plan: A plan for investment, a plan for reform. London: $\mathrm{DH}, 2000$. 